\title{
Non-Carcinogenic Solvents as Alternative to Benzene for Wood Extractives Determination
}

\author{
Ramadan A. Nasser and Hamad A. Al-Mefarrej 1
}

\begin{abstract}
Wood extractives are very important to identify the suitability of wood to different purposes and for wood industries. A solvent mixture of benzene and ethanol is widely recognized as a standard method for removing most wood extractives, in order to determine the chemical composition of wood. Benzene is a carcinogenic substance and exposure to it is one of the most common chemical health risks. Accordingly, benzene as a solvent should be substituted by less hazardous ones. In the current study, six hardwood species were used. Extraction of wood particles was carried out by Soxhlet apparatus in two phases. One of them is a single-phase solvent (benzen

$e$, acetone, ether and ethanol), and the other is a combined-phase solvent. In the latter, the specimens were extracted in three steps with benzene-ethanol, ethanol and distilled water according to ASTM method, whereas other specimens were extracted following ASTM method with replacing benzene by either acetone or ether. As a reference basis, the results of combined-phase were compared to NREL method (extracting the specimens with ethanol for 24 hours). The objective of this study was to find a less hazardous solvent replacement to benzene. Results indicate that as comparing to ASTM method, the two alternative methods removed the same amounts of wood extractives for the six wood species studied. Our results indicated that extraction of the six wood species with either acetone-ethanol or ether-ethanol gave closely results that were comparable to benzene-ethanol. Therefore, they can be considered as replacement solvents to benzene-ethanol in ASTM method. Extractives content for all the six wood species achieved by the standard method of NREL were significantly lower than that extracted by either ASTM method or each of the two alternative methods. The method of specimen extraction had a significant effect on lignin and hemicellulose content. The specimens extracted by NREL method had the highest hemicellulose content and the lowest extractive and lignin contents of other methods.
\end{abstract}

Keywords: Extractives content, benzene-ethanol, carcinogenic substance, chemical composition of wood, cellulose, lignin, hemicellulose, NREL, ASTM,

\section{INTRODUCTION}

In addition to the major cell wall components (cellulose, hemicellulose and lignin) which are structural components of high molecular weight (Haygreen and Bowyer, 1989), wood contains secondary components of non-structural, low molecular weight that are categorized as extractives. The latter are soluble in neutral, non-polar, organic solvents and cold water (Fengel and Wegener, 1989). Generally the total extractive content of wood (based on oven-dry weight) varies between less than 1 to $5 \%$, but can be up to $30 \%$ in extreme cases (Hillis, 1972, and Shebani et al., 2008). The amount and composition of extractives differ depending on the solvent used (Sefara and Birkett, 2004), and they differ markedly in various parts of the same tree and species (Horvath, 2007), harvesting season (Zabel and Morrell, 1992), silvicultural practices (Abdel-Aal and Kayad, 2007) and storage time (Silverio et al., 2008).

Although wood extractives represent merely a few percentage of the entire wood composition, they have negatively influenced many wood characteristics i.e., thermal stability (Shebani et al., 2008), shrinkage (Kayad, 2007), adhesion and wettability (Choong, 1970), specific gravity and compressive strength (Badran and El-Osta, 1977 and El-Osta et al., 1980) and bending strength (Al-Mefarrej, 1985). They are also responsible for many problems in wood industries like pulp production and papermaking (Silverio et al, 2008), particleboard (Vital et al, 1980), and wood-cement composites (Al-Mefarrej and Nasser, 2008). However, most of extractive compounds of wood are toxic to both fungi and insects so it gave wood its natural durability (Arango, et al., 2004). On the other hand, some wood extractives, like waxes, fats and sugars have little economic significance, but others, such as rubber and resin are of considerable economic importance (Haygreen and Bowyer, 1989).

It is necessary for extractive materials to be removed from samples prior to the summative analysis of wood. In the meantime, extractive content determination and its composition are very important to identify the suitability of wood for different purposes and for wood industries.

Wood extractives can be extracted by means of neutral organic solvents. Standard methods such as ASTM (1989) and Tappi (1998) are commonly used for quantitative determination of extractives in wood using Soxhlet apparatus with different solvents including

\footnotetext{
${ }^{1}$ Plant Production Department, College of Food and

Agricultural Sciences, King Saud University,

P.O. Box 2460 Riyadh 11451, Saudi Arabia

Received August 17, 2009, Accepted August 25, 2009
} 
water, alcohol, benzene and ether. A solvent mixture consisting of benzene-ethanol $2: 1(\mathrm{v} / \mathrm{v})$ is widely recognized as a standard method for the removal of most extractives of wood (ASTM, 1989). On the other hand, extraction of woody biomass samples with $95 \%$ ethanol for 24-hours using Soxhlet apparatus has been found to be an effective, non-toxic alternative solvent to benzene. This method has been accepted by ASTM as standard test method for the determination of extractives in biomass feedstocks (Ehrman, 1994).

It is known that exposure to solvent (i.e., benzene) is one of the most common chemical health risks in work places (Proctor, 1988). Benzene is an organic solvent, colourless liquid and it is a carcinogenic solvent. The threshold limit value (TLV) in the workplace air over an 8- hour working day is $10 \mathrm{ppm}$ or $32 \mathrm{mg} . \mathrm{m}^{-3}$ (ILO, 1983). Exposure to low and high concentrations of benzene may cause dizziness, irregularities in the heart beat which can lead to death (CIS, 2008). Accordingly and due to the highly hazardous benzene as a solvent should be substituted by less hazardous ones (CIS, 2008). Researchers have been working to find a new procedure that could alternately replace these methods utilizing alternative solvents. In this area, Sefara and Brikett (2004) found that solvents which gave yields that were comparable to benzene-ethanol were acetone and mixture of toluene and ethanol (75 and $25 \%$, respectively).

Virtually, there are little attempts in the literature to find an alternative solvent to replace benzene with low toxicity and give effective and real results for wood extraction. It has been known that before suggesting proper utilization of wood, it is essential to evaluate their basic technological properties. Chemical composition of wood is one of the important technological properties which can provide the best utilization and determine its suitability for any wood industry.

Therefore, the primary objective of the current study was to evaluate the feasibility of using alternative solvents with low toxicity to replace benzene for determination the total extractives content. The second objective was to investigate the effect of extraction methods on the main chemical components of wood.

\section{MATERIALS AND METHODS}

For the current investigation, one tree from six hardwood species was randomly selected grown at the Agricultural Research Experimental Station of King Saud University near Derab, Riyadh. Four of them are Acacia ehrrenbergiana Hayne, A. farnesiana (L.), A. gerrardi var. najdensis Chaudhary and $A$. tortilis var. sperocarpa Hochstex. These trees were planted in September 2001. The other two species were selected from Albizia lebbeck (L.) that were planted in 1998 and Tamarix aphylla L. that was selected from a windbreak (about 35-years old). All trees used in this study were irrigated by treated sewage effluent.

Once selected trees were felled at the end of 2007 , one bolt $(30 \mathrm{~cm})$ at the height of $30-\mathrm{cm}$ from the stem base was taken and sawn longitudinally into several boards with thickness of $2-\mathrm{cm}$ and staked on a pellet for air-drying in the laboratory to reach the equilibrium moisture content (about 9-11\%). After air drying and debarking, all woody material of each species was reduced separately into small pieces to facilitate grinding process. These samples, thereafter, were ground into wood meal using a laboratory grinding mill. Particles which pass through a 40- mesh screen and retained on a 60- mesh screen were used for wood chemical analysis.

\section{Extractive content determination:}

Extraction of wood particles was carried out using Soxhlet apparatus in two different phases, one of them is single-phase solvents (benzene, acetone, ether or alcohol) and the other is combination of solvents in successively three steps including ASTM (with benzene/alcohol mixture). On the other hand, extraction by ethyl alcohol for 24- hours (NERL) as the standard method was used (Table 1).

\section{Table 1. Methods of wood extraction used in the current study}

\begin{tabular}{llccccc}
\hline \multicolumn{1}{c}{$\begin{array}{c}\text { Method of } \\
\text { Extraction }\end{array}$} & \multicolumn{1}{c}{ Solvent } & Time & Solvent & Time & Solvent & Time \\
\cline { 2 - 7 } Single-phase & Benzene & 4 & - & - & - & - \\
Single-phase & Acetone & 4 & - & - & - & - \\
Single-phase & Ether & 4 & - & - & - & - \\
Single-phase & Alcohol & 4 & - & - & - & - \\
NREL & Alcohol & 24 & - & - & - & - \\
ASTM $^{* *}$ & Benzene/alcohol & 4 & Alcohol & 4 & Water & 4 \\
$\mathrm{ALT}_{1}$ & Acetone/alcohol & 4 & Alcohol & 4 & Water & 4 \\
$\mathrm{ALT}_{2}$ & Ether/alcohol & 4 & Alcohol & 4 & Water & 4 \\
\hline
\end{tabular}

$\mathrm{ALT}_{1}$ and $\mathrm{ALT}_{2}$ mean replace benzene in ASTM standard by another solvent (acetone or ether, respectively).

*According to the NREL Chemical Analysis and Testing Task Laboratory Analytical Procedure (1994).

** According to ASTM standard D1105-84 (1989). 
Air-dried wood meal (about 2 grams, 40-60 mesh) was extracted using a Soxhlet apparatus in successively three steps with benzene-ethanol mixture, ethanol and distilled water. Four hours were allowed for the first two steps, while hot water extraction was carried out for three hours with changing water every hour (ASTM, 1989). After each step, specimens were spread out in a thin layer and allow drying in the air until free of solvent. The extracted specimens were oven-dried at $100 \pm 3{ }^{\circ} \mathrm{C}$ to a constant weight then the extractive content was calculated based on the oven-dry weight. Other specimens were extracted following ASTM methods without benzene which was replaced by either acetone or ether. In addition, another wood samples were extracted by single-phase solvents using each of benzene, acetone, alcohol or ether for four hours.

\section{Determination of the main chemical components of wood:}

Chemical analysis and procedures for the other wood components (cellulose, hemicellulose, and lignin) were carried out using extractive-free wood meal according to the methods described by Nikitin (1960), Rozmarin and Simionescu (1973), and ASTM D110684 (1989), respectively. For each species, the contents of cellulose, hemicellulose and lignin were determined using extractive-free wood meal after extracted by NREL, ASTM, $\mathrm{ALT}_{1}$ (acetone is an alternative solvent to benzene) and $\mathrm{ALT}_{2}$ (ether is an alternative solvent to benzene) methods to study the effect of extraction method on the contents of the main chemical components of wood as comparing to ASTM standard (including benzene).

Table 2. Mean values*of extractives contents**(\%) for the six wood species extracted by different solvents

\begin{tabular}{lcccccc}
\hline & \multicolumn{2}{c}{ Wood species } \\
\hline \multirow{2}{*}{ Solvent ${ }^{+}$} & $\begin{array}{c}\text { Tamarix } \\
\text { aphylla }\end{array}$ & $\begin{array}{c}\text { Albizia } \\
\text { lebbeck }\end{array}$ & $\begin{array}{c}\text { Acacia } \\
\text { farnesiana }\end{array}$ & $\begin{array}{c}\text { Acacia } \\
\text { ehrrenbergiana }\end{array}$ & $\begin{array}{c}\text { Acacia } \\
\text { gerrardi }\end{array}$ & $\begin{array}{c}\text { Acacia } \\
\text { tortilis }\end{array}$ \\
\hline Benzene & $5.06^{\mathrm{B}}$ & $1.24^{\mathrm{D}}$ & $3.04^{\mathrm{D}}$ & $1.79^{\mathrm{C}}$ & $2.51^{\mathrm{C}}$ & $0.93^{\mathrm{C}}$ \\
& $(0.06)$ & $(0.23)$ & $(0.11)$ & $(0.25)$ & $(0.22)$ & $(0.12)$ \\
Ethanol & $6.58^{\mathrm{A}}$ & $5.06^{\mathrm{A}}$ & $5.08^{\mathrm{A}}$ & $3.83^{\mathrm{A}}$ & $6.14^{\mathrm{A}}$ & $2.53^{\mathrm{A}}$ \\
& $(0.27)$ & $(0.16)$ & $(0.50)$ & $(0.27)$ & $(0.20)$ & $(0.30)$ \\
Acetone & $2.17^{\mathrm{C}}$ & $2.31^{\mathrm{B}}$ & $4.74^{\mathrm{B}}$ & $1.86^{\mathrm{C}}$ & $2.43^{\mathrm{C}}$ & $0.88^{\mathrm{C}}$ \\
& $(0.48)$ & $(0.15)$ & $(0.26)$ & $(0.22)$ & $(0.15)$ & $(0.15)$ \\
Ether & $1.27^{\mathrm{D}}$ & $1.72^{\mathrm{C}}$ & $3.81^{\mathrm{C}}$ & $2.47^{\mathrm{B}}$ & $3.71^{\mathrm{B}}$ & $1.47^{\mathrm{B}}$ \\
& $(0.22)$ & $(0.19)$ & $(0.23)$ & $(0.17)$ & $(0.12)$ & $(0.13)$ \\
\hline
\end{tabular}

*Each value is an average of 6 specimens.

**Extractive content was calculated based on oven-dry weight.

+Extraction was carried out using Soxhelt apparatus for 4 hours for each solvent.

Means with the same letters in column are not significant differences at 0.05 level of probability according to LSD test.

( ) Values in parentheses are standard deviations.
The analysis of variance indicated that the differences between extraction methods and wood species as well as the interaction between them were highly significant for the extractives content. The mean values and standard deviations of the extractives content as affected by the different solvents (single-phase) for the six wood species used in the current study are presented in Table 2. It can be seen from this table that each solvent extract varying amounts of extractive compound were found. This result is in agreement with the finding of Sefara and Birkett (2004), which may be attributed to the differences in the chemical properties, especially the polarity, of used solvents.

The data in Table (2) and Fig. (1) revealed that the amounts of extractives soluble in the different organic solvents of the different wood species are quit different. The benzene-ethanol soluble extractives content compressing waxes, fats, resins, and some gums (ASTM 1989 and Tappi 1998). The process of ether extraction can remove waxes, fats, resins, oils and similar materials (ASTM, 1989).

Generally, the amounts of the dissolved extractives in ethanol solvent were the highest in all the six wood species as compared to other solvents. These amounts ranged between $2.53 \%$ for Acacia sperocarpa and $6.58 \%$ for Tamarix aphylla.

With regard to the amount of extractives in each wood species as affected by the method of samples extraction by different solvents (single-phase), it can be 


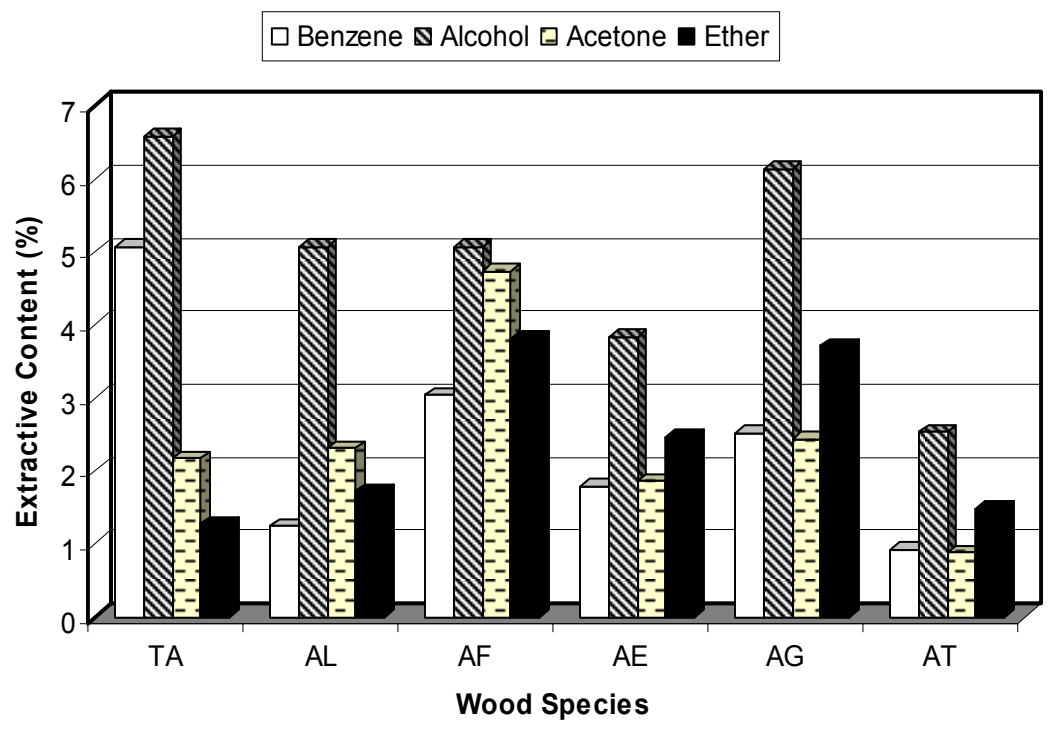

Fig. 1. The yield of extractive substances from different wood species extracted by different solvents (For legend see Table 2)

noted from the results (Table 2 and Fig. 1) where three patterns were found. The first pattern was obtained with Acacia gerrardi, A. eherenbegina, and A. sperocarpa. In this pattern, the extraction process by ethanol solvent gave the highest value of extractives content followed by acetone then extraction by either benzene or ether solvents. No significant differences were obtained between acetone and ether solvents. The second pattern was observed with Acacia farnesiana and Albizia lebbeck. There are significant differences between all the four solvents used. Extraction by ethanol solvent gave the highest extractives content followed by acetone then ether and benzene extraction. The third pattern was obtained with Tamarix aphylla and showed an adverse trend where the rank orders is ethanol, benzene, acetone and ether. In this pattern, the extractives content was the highest $(6.58 \%)$ with ethanol extraction, while the lowest one was obtained with ether extraction (1.27\%).

The low extraction power of some solvents as compared to ethanol is may be attributed to their lower polarity index as seen in Table 1 and therefore lacking the ability to extract more polar compounds in the wood. In the same time, these species may be having a lower amount of polar components which dissolving in these solvents or having a higher amounts of non-polar compounds.

Effect of extraction method on the determination of extractives content:

The analysis of variance indicated that the differences between extraction methods and wood species as well as the interaction between them were highly significant for the extractives content. Table (3) and Fig. (2) shows the mean values and standard deviations of the extractive content determined by the different methods including standard methods (ASTM and NREL) and alternative methods (acetone or ether as alternative to benzene) for the six wood species used in the current study.

Generally it can be seen from Table (3) that extraction of wood samples of the six wood species used in the current study by NREL method (24 hour ethanol extraction) removed significantly lowest amounts of extracted compounds compared to other methods of extraction including ASTM method. With a few expectations, no significant differences were obtained in the amount of extractives isolated by ASTM method including benzene and each of the two alternative methods used in this study (Table 3 and Fig. 2).

It is clear that no significant differences were obtained in the extractive content values which were determined by alternative extraction method including acetone as alternative to benzene (acetone-ethanol mixture) and the standard method of ASTM (benzeneethanol) for all wood species used in this study except Albizia lebbeck. The amount of extractives which were extracted by acetone-ethanol mixture for Albizia lebbeck (10.41\%) was significantly higher than that determined by ASTM method $(9.73 \%)$. The same trend was observed with comparing ASTM method to etherethanol mixture (ether is alternative to benzene) but in this case Acacia ehrenbergiana had higher extractive content $(6.72 \%)$ when extracted by ether-ethanol 
401

Ramadan A. Nasser and Hamad A. Al-Mefarrej: Non-Carcinogenic Solvents as Alternative to Benzene for Wood Extractives Determination

mixture than ASTM method $(6.14 \%)$ and the differences between them were significant. With exceptions of Albizia lebbeck and Acacia ehrengergiana, no significant differences were observed in the extractives content for the rest four wood species between ASTM method and each of the two alternative methods.

As compared to ASTM method, the two alternative methods used in this work were removed the same

Table 3. Mean values* of total extractives content (\%) of wood for the six wood species extracted by different combination of solvents

\begin{tabular}{|c|c|c|c|c|c|c|}
\hline \multirow[b]{2}{*}{$\begin{array}{l}\text { Method of } \\
\text { Extraction }\end{array}$} & \multicolumn{6}{|c|}{ Wood species } \\
\hline & $\begin{array}{l}\text { Tamarix } \\
\text { aphylla }\end{array}$ & $\begin{array}{l}\text { Albizia } \\
\text { lebbeck }\end{array}$ & $\begin{array}{c}\text { Acacia } \\
\text { farnesiana }\end{array}$ & $\begin{array}{c}\text { Acacia } \\
\text { ehrrenbergiana }\end{array}$ & $\begin{array}{c}\text { Acacia } \\
\text { gerrardi }\end{array}$ & Acacia tortilis \\
\hline \multirow[t]{2}{*}{$\mathrm{ASTM}^{+}$} & $16.22^{\mathrm{A}}$ & $9.73^{\mathrm{B}}$ & $13.69^{\mathrm{A}}$ & $6.12^{\mathrm{B}}$ & $13.78^{\mathrm{A}}$ & $5.86^{\mathrm{A}}$ \\
\hline & $(0.29)$ & $(0.17)$ & $(0.11)$ & $(0.34)$ & $(0.07)$ & $(0.14)$ \\
\hline \multirow[t]{2}{*}{$\mathbf{A L T R}_{1}$} & $15.89^{\mathrm{A}}$ & $10.41^{\mathrm{A}}$ & $14.03^{\mathrm{A}}$ & $6.40^{\mathrm{AB}}$ & $13.77^{\mathrm{A}}$ & $5.98^{\mathrm{A}}$ \\
\hline & $(0.25)$ & $(0.15)$ & $(0.63)$ & $(0.34)$ & $(0.93)$ & $(0.17)$ \\
\hline \multirow[t]{2}{*}{$\mathbf{A L T R}_{2}$} & $15.39^{\mathrm{A}}$ & $9.88^{\mathrm{B}}$ & $14.05^{\mathrm{A}}$ & $6.72^{\mathrm{A}}$ & $13.47^{\mathrm{A}}$ & $6.13^{\mathrm{A}}$ \\
\hline & $(0.22)$ & $(0.05)$ & $(0.20)$ & $(0.29)$ & $(0.85)$ & $(0.10)$ \\
\hline \multirow[t]{2}{*}{ NREL $^{++}$} & $7.14^{\mathrm{B}}$ & $6.37^{\mathrm{C}}$ & $7.56^{\mathrm{B}}$ & $4.10^{\mathrm{C}}$ & $6.12^{\mathrm{B}}$ & $3.42^{\mathrm{B}}$ \\
\hline & $(0.36)$ & $(0.03)$ & $(0.12)$ & $(0.49)$ & $(0.31)$ & $(0.13)$ \\
\hline
\end{tabular}

*Each value is an average of 4 specimens.

$\mathrm{ALT}_{1}$ and $\mathrm{ALT}_{2}$ mean alternative solvents to benzene in ASTM standard by acetone and ether, respectively.

+According to American Standard Testing Method (ASTM) D1105-84 (1989).

++According to the NREL Chemical Analysis and Testing Task Laboratory Analytical Procedure \#005 (1994).

All extraction was carried out in three steps, except for NREL which is extracted by alcohol as solvent for 24 hours. For more detail see Table (1).

Means with the same letters in column are not significantly difference according to LSD test at 0.05 level of probability.

( ) Values in parentheses are standard deviations.

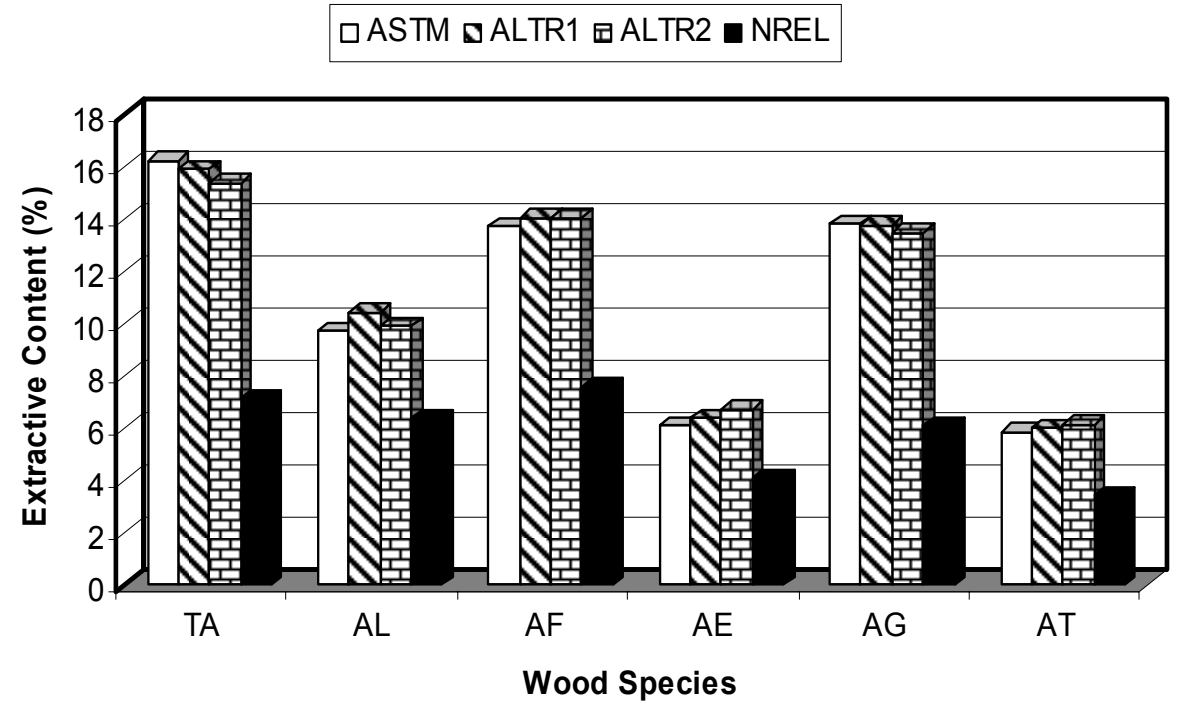

Fig. 2. The yield of extractive substances from different wood species extracted by different combination solvents (For legend see Table 2) 
Effect of extraction methods on the content of chemical constituents of wood:

Regarding the wood chemical constituents, the differences between the six species used in the current study were highly significant. According to the ASTM methods, the highest value of extractives content $(16.27 \%)$ was obtained with Tamarix aphylla, while the lowest value $(5.78 \%)$ was recorded with Acacia sperocarpa. The highest and lowest values of cellulose content were recorded with Acacia gerrardi (49.28\%) and Acacia farnesiana (41.98\%), respectively. Acacia farnesiana had the highest hemicellulose content (27.93\%) and Acacia ehrengergiana had the lowest

Table 4. Wood chemical constituents as af extraction for six wood species studied

\begin{tabular}{|c|c|c|c|c|c|c|c|c|}
\hline \multirow{2}{*}{$\begin{array}{c}\text { Wood } \\
\text { Species }\end{array}$} & \multirow{2}{*}{$\begin{array}{c}\text { Extraction } \\
\text { Method }\end{array}$} & \multicolumn{2}{|c|}{ Extractive $^{1}$} & \multirow{2}{*}{$\begin{array}{c}\text { Cellulose }^{2} \\
\%\end{array}$} & \multicolumn{2}{|c|}{ Hemicellulose $^{2}$} & \multicolumn{2}{|c|}{ Lignin $^{2}$} \\
\hline & & $\%$ & $\Delta$ & & $\%$ & $\Delta$ & $\%$ & $\Delta$ \\
\hline \multirow[t]{4}{*}{ Tamarix aphylla } & ASTM & $16.22^{\mathrm{A}}$ & - & 45.54 & $23.99^{\mathrm{BC}}$ & - & $26.36^{\mathrm{A}}$ & - \\
\hline & $\mathrm{ALT}_{1}$ & $15.89^{\mathrm{A}}$ & -2.9 & 45.62 & $24.37^{\mathrm{B}}$ & +1.6 & $25.92^{\mathrm{A}}$ & -1.7 \\
\hline & $\mathbf{A L T}_{2}$ & $15.39^{\mathrm{B}}$ & -4.4 & 45.30 & $23.41^{\mathrm{C}}$ & -2.4 & $26.35^{\mathrm{A}}$ & -0.04 \\
\hline & NREL & $7.14^{\mathrm{C}}$ & -57.0 & 46.67 & $26.67^{\mathrm{A}}$ & +11.2 & $20.14^{\mathrm{B}}$ & -23.6 \\
\hline \multicolumn{2}{|c|}{$\begin{array}{l}\text { Significant } \\
\end{array}$} & $* *$ & & $\mathrm{NS}$ & $* *$ & & $*$ & \\
\hline \multirow[t]{4}{*}{ Albizia lebbeck } & ASTM & $9.73^{\mathrm{B}}$ & - & 45.66 & $24.79^{\mathrm{B}}$ & - & $25.06^{\mathrm{A}}$ & - \\
\hline & $\mathbf{A L T}_{1}$ & $10.41^{\mathrm{A}}$ & +6.2 & 45.40 & $25.00^{\mathrm{B}}$ & +0.9 & $26.02^{\mathrm{A}}$ & +3.8 \\
\hline & $\mathbf{A L T}_{\mathbf{2}}$ & $9.88^{\mathrm{B}}$ & -1.0 & 45.79 & $24.29^{\mathrm{B}}$ & -2.0 & $25.73^{\mathrm{A}}$ & +2.7 \\
\hline & NREL & $6.37^{\mathrm{C}}$ & -34.9 & 46.47 & $26.47^{\mathrm{A}}$ & +6.8 & $20.43^{B}$ & -18.5 \\
\hline \multicolumn{2}{|c|}{ Significant } & $* *$ & & NS & $* *$ & & $* *$ & \\
\hline \multirow[t]{4}{*}{ Acacia farnesiana } & ASTM & $13.69^{\mathrm{A}}$ & - & 41.98 & $27.93^{\mathrm{BC}}$ & - & $23.51^{\mathrm{A}}$ & - \\
\hline & $\mathbf{A L T}_{1}$ & $14.03^{\mathrm{A}}$ & +10.9 & 41.93 & $28.38^{\mathrm{B}}$ & +1.5 & $23.02^{\mathrm{A}}$ & -2.1 \\
\hline & $\mathbf{A L T}_{2}$ & $14.05^{\mathrm{A}}$ & +10.8 & 42.17 & $27.08^{\mathrm{C}}$ & $-3 / 0$ & $21.60^{\mathrm{B}}$ & -8.1 \\
\hline & NREL & $7.56^{\mathrm{B}}$ & -40.7 & 42.61 & $30.07^{\mathrm{A}}$ & +7.7 & $19.31^{\mathrm{C}}$ & -17.9 \\
\hline \multicolumn{2}{|c|}{ Significant } & $* *$ & & NS & $* *$ & & $*$ & \\
\hline \multirow[t]{4}{*}{ Acacia gerrardi } & ASTM & $13.78^{\mathrm{A}}$ & - & 48.28 & $25.68^{\mathrm{B}}$ & - & $24.27^{\mathrm{A}}$ & - \\
\hline & $\mathrm{ALT}_{1}$ & $14.03^{\mathrm{A}}$ & -2.2 & 49.36 & $23.36^{\mathrm{C}}$ & -9.0 & $23.88^{\mathrm{A}}$ & -1.2 \\
\hline & $\mathbf{A L T}_{2}$ & $14.05^{\mathrm{A}}$ & -3.3 & 48.60 & $24.39^{\mathrm{C}}$ & -5.0 & $23.19^{\mathrm{B}}$ & -4.5 \\
\hline & NREL & $6.12^{\mathrm{B}}$ & -56.1 & 48.94 & $29.12^{\mathrm{A}}$ & +13.4 & $20.37^{C}$ & -16.1 \\
\hline \multicolumn{2}{|c|}{ Significant } & $* *$ & & NS & $* *$ & & $*$ & \\
\hline \multirow[t]{4}{*}{ Acacia tortilis } & ASTM & $5.86^{\mathrm{A}}$ & - & 48.17 & $23.25^{\mathrm{B}}$ & - & $25.37^{\mathrm{A}}$ & - \\
\hline & $\mathbf{A L T}_{1}$ & $5.98^{\mathrm{A}}$ & -0.9 & 48.34 & $22.80^{\mathrm{C}}$ & -1.9 & $24.31^{\mathrm{B}}$ & -4.2 \\
\hline & $\mathbf{A L T}_{2}$ & $6.13^{\mathrm{A}}$ & +5.2 & 47.92 & $22.88^{\mathrm{B}}$ & -1.6 & $24.86^{\mathrm{C}}$ & -2.0 \\
\hline & NREL & $3.42^{\mathrm{B}}$ & -39.6 & 49.33 & $24.97^{\mathrm{A}}$ & +7.4 & $\mathbf{2 0 . 5 6}{ }^{\mathrm{D}}$ & -19.0 \\
\hline \multicolumn{2}{|c|}{ Significant } & $* *$ & & NS & $* *$ & & $*$ & \\
\hline Acacia & ASTM & $6.12^{\mathrm{B}}$ & - & 48.23 & $18.47^{\mathrm{B}}$ & - & $23.45^{\mathrm{A}}$ & - \\
\hline \multirow[t]{3}{*}{ ehrenbergiana } & $\mathbf{A L T}_{1}$ & $6.40^{\mathrm{AB}}$ & +6.2 & 48.89 & $17.83^{\mathrm{B}}$ & -3.5 & $23.80^{\mathrm{A}}$ & +1.5 \\
\hline & $\mathbf{A L T}_{2}$ & $6.72^{\mathrm{A}}$ & +4.4 & 48.51 & $18.40^{\mathrm{B}}$ & -0.4 & $23.50^{\mathrm{A}}$ & -0.6 \\
\hline & NREL & $4.10^{C}$ & -32.5 & 47.86 & $20.67^{\mathrm{A}}$ & +10.6 & $19.35^{\mathrm{B}}$ & -17.5 \\
\hline \multicolumn{2}{|c|}{ Significant } & $* *$ & & NS & $* *$ & & $*$ & \\
\hline
\end{tabular}

1: Each value is an average of 6 specimens.

2: Each value is an average of 4 specimens.

For each species in the same column, means having the same letter are not significantly different at 0.05 level of probability according to LSD test.

NS: Not significant.

$\Delta$ Change percent based on ASTM method.

content $(18.47 \%)$. Regarding the lignin content, it can be noted from Table (4) that Tamarix aphylla gave the highest value of lignin content (26.36\%), while Acacia ehrengergiana and Acacia farnesiana recorded the lowest values (23.45 and $23.51 \%$, respectively).

For each species, the cellulose content of wood was not affected by the methods of samples extraction and the differences between the four extraction methods were not significant. However, the method of samples extraction had a significant effect on the mean contents of extractives, hemicellulose and lignin as shown in Table 4.

affected by different methods of specimen 
Significant differences in hemicellulose and lignin contents have been found between NREL method and either ASTM method or the two alternative methods (acetone and ether as replacement to benzene). It can be seen from Table (4) that specimens extracted by NREL method had the highest hemicellulose content values and the lowest extractives and lignin contents compared to

the other methods. Using the change percentage of chemical constituents to ASTM method, it can be seen from this table that the highest effect $(>10 \%)$ was obtained with extractives content (maximum changes were -57.0 and $-56.1 \%$ for Tamarix aphylla and Acacia gerrardii, respectively) followed by lignin content (maximum change was $-23.6 \%$ for Tamarix aphylla), while the lowest effect was obtained with hemicellulose content (maximum change was $+13.4 \%$ for Acacia gerrardii). However, no significant differences were detected in cellulose content which determined using specimens extracted by different methods.

The differences in hemicellulose and lignin contents for the specimens extracted by NREL and the other methods including ASTM method was because the former method did not remove all wood extractive materials from specimens furthermore these specimens after extraction could not be considered as extractedfree materials. Based on this result the hemicellulose content will increase, however lignin content will decrease. In the case of NREL method and for lignin content, with the assumption that the lignin content of the specimen is constant and which increase the ovendry weight of the specimen due to inclusion of some extractive materials which was not removed by ethanol, the lignin content is decreased.

Comparing hemicellulose and lignin contents determined by ASTM method using the alternative methods in this work, no significant differences were detected and the differences between each of alternative method and ASTM method as a percentage to the later are quite low (less than $<10 \%$ ) and these differences could be considered as natural and random error.

\section{CONCLUSIONS AND RECOMMENDATIONS}

The following conclusions are drawn from the data obtained in this study:

1- Extraction by ethanol solvent gave the highest extractives content for all wood species studied, followed by acetone then ether and benzene.

2- NREL method (24 hours ethanol extraction) removed significantly lowest amounts of extractives compared to other methods of extraction including ASTM method.
3- The difference in the amount of extractives extracted by using ASTM method and each of the two alternative methods used in this study were not significantly different.

4- Extraction of the six wood species with either acetone-ethanol or ether-ethanol mixture gave closely results to those that were comparable to benzene-ethanol mixture.

5- It can be concluded that using mixtures of acetoneethanol and/or ether-ethanol are considerable replacement solvents to benzene-ethanol in ASTM method to determine the extractive content of wood.

6- The wood specimens extracted by NREL method had the highest hemicellulose content values and the lowest extractive and lignin contents compared to the other standard methods.

7- No significant differences were detected in cellulose content which determined using wood specimens extracted by different methods.

8- Using NREL method for extractive content determination, mention must be made if we need to determine the hemicellulose and lignin content of wood.

9- NREL method gave significantly low values of wood extractive content as compare to ASTM method due to the presence of few water soluble extractable materials.

\section{REFERENCES}

American Society for Testing and Materials. 1989. Standard test methods for preparation of extractive-free wood. ASTM D 1105-84. Philadeliphia, Pa. U.S.A.

Abdel Aal, M.A.M, and G.R. Kayad. 2007. Effect of thinning on chemical composition of some trees grown in Egypt. Egypt J. of Appl. Sci., 22 (11): 167-178.

Al-Mefarrej, H.A. 1985. Bending strength of Tamarix aphyaal (L.) Karst auth.) as related to specific gravity and extractive content. M.S.c. Thesis, College of Agriculture, King Saud University, Riyadh.

Al-Mefarrej, H.A. and R.A. Nasser. 2008. Suitability of four lignocellulosic materials in Saudi Arabia for cementbonded particleboard industry and effect of some treatments on their compatibility with Portland cement. Alex. J. Agric. Res. Vo. (53) No. (3): 117-125 .

Arango, R.A., F. Green, K. Hintz and R. B. Miller. 2004. Evaluating the natural durability of native and tropical wood species against Reticulitermes flavipes. The $35^{\text {th }}$ Annual Meeting Lijubljana, Slovenia, 6-10 June, 2004. 
Badran, O.A. and M.L.M. EL-Osta. 1977. Influence of specific gravity and extractive content on maximum crushing strength of wood. Alex. J. Agric. Res. 25 (3): 535-540.

EL-Osta, M.L.M., O.A. Badran, E.M.A. Ajoung. 1980. Crushing strength of three Sudanese tropical hardwoods in relation to specific gravity, extractive and lignin content. Wood Sci. 13 (4): 225-232.

Choong, E.T. 1970. the effect of extractives on shrinkage and other hygroscopic properties of ten southern pine woods. Wood and Fiber Vol. 1 No. 2 pp: 124-132.

Ehrman, T. 1994. Chemical analysis and testing task laboratory analytical procedure: Standard method for the determination of extractive in biomass. Procedure \#010, pp: $1-7$,

Fengel, D., and G. Wengener. 1989. Wood chemistry, ultrastrucuture, reactions. De Gruyter, Berline.

Haygreen, J.G. and J.L. Bowyer. 1989 . Forest Products and Wood Science. The IOWA State Uni. Press/Ames., pp. 495.

Hillis, W.E. 1972. Properties of eucalypt woods of importance to the pulp and paper industry. Appita 26 (2): 113-122.

Horvath, A.L. 2006. Solubility of structurally complicated materials: I. Wood. J. Phys. Chem. Ref. Data, 35 (1): $77-$ 92.

International Occupational Safety Health Information (CIS). 2008.Solvents.Benzene. http/internationaloccupationalsafety.centre.htm.

ILO. 1983. International Labour Organisation: Encyclopedia of Occupational Health and Safety, Vol I -III, Geneva.

Kayad, G.R. 2007. Variation in shrinkage properties of some hardwood species. Egypt J. of Appl. Sci. 22 (11): 150166.
Lehmann, W. F. 1970. Resin efficiency in particleboard as influenced by density, atomization and resin content. Forest Prod. J. 20 (11): 48-54.

Nikitin, V.M. 1960. "Himia drevesini I telliuloze" Goslesbumiz_dat, M_L. Pg. 233. Cimia Lemnului SI A Celuloze I Vol I si II, 1973 (Roominess).

NREL CAT Task Laboratory Analytical Procedure. 1994. Standard Method for the Determination of extractives in Biomass.

Proctor, N.H., J.P. Hughes and M.L. Fischman. 1988. Chemical Hazards of the Workplace, R.R, Sec. Ed., Donnelly \& Sons Co.,Inc.

Rozmarin, G. and C. Simionescu. 1973. Determining hemicellulose content. Wood Chemistry and Cellulose 2:392 (Romanian).

Sefara, N. L. and M. Birkett. 2004. Development of an alternative solvent to replace benzene in the determination of organic soluble extractives in wood. African Pulp and Paper Week, pp: 1-7.

Shebani, A. N., A. J. van Reenen and M. Meincken. 2008. The effect of wood extractives on the thermal stability of different wood species. Thermochimica Acta Vo. 471: 43-50.

Silverio, F. O., L.C.A. Barbosa, C.R.A Maltha, P.H. Fidencio, M.P. Cruz, D.P. Veloso, and A.F. Milanez. 2008. Effect of storage time on the composition and content of wood extractives in Eucalyptus cultivated in Brazil. Ioresource Technology 99: 4878-4886.

TAPPI. 1998. Technical Association of the Pulp and Paper Industry, Test Methods, Atlanta.

Vital, B. R., J. B. Wilson and P.H. Kanarek. 1980. Parameters affecting dimensional stability of flakeboard and particleboard. Forest Prod. J. 30 (12): 23-29.

Zabel, R.A., and J.J. Morrell. 1992. Wood microbiology: decay and its prevention. Academic Press, London and New York. 


\title{
[المض الم
}

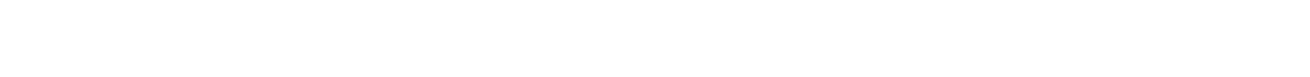

\author{
رضلن عبد السيد ناصر، لـدعبد المين إلهزج
}

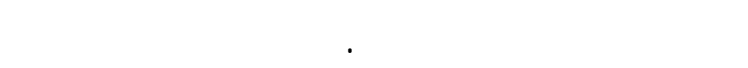

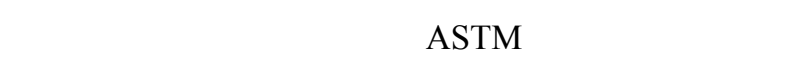
الكمال

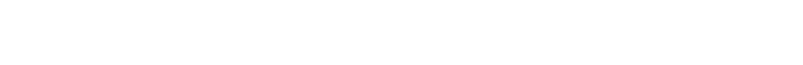

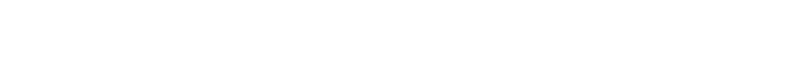

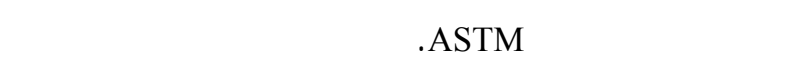

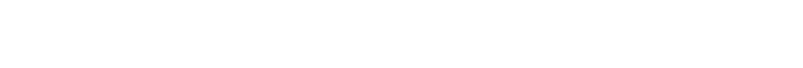

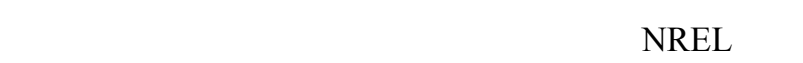

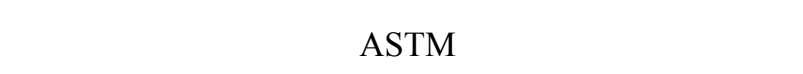

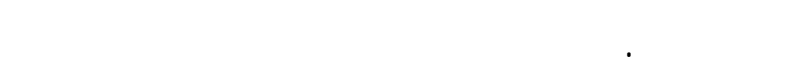

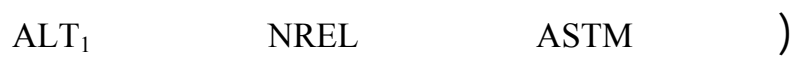

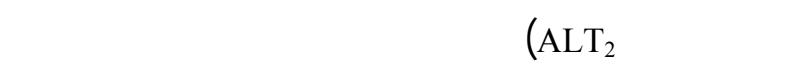

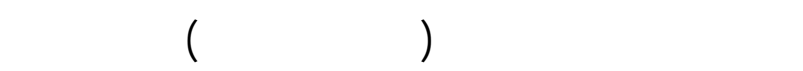

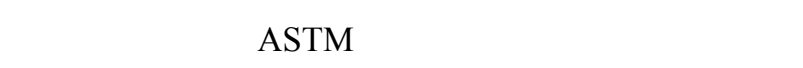
NREL

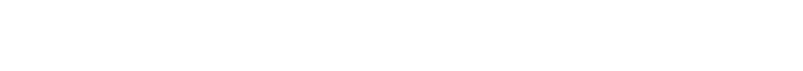

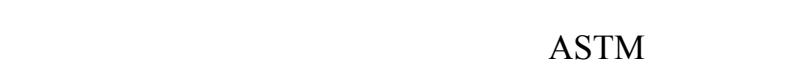

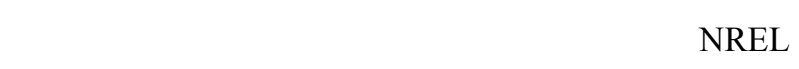
الهثية ول لستخلاص العينت بذه الطرية يؤزخ معنوياً على قيم

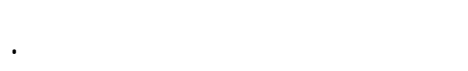

تهنت اللمستخلصات المثيبة هلة جداً لتحديد مدى صلاحية الهثب للأغرلن الخختلة والصناعلت الهثبية. يوصي بلستخدم [ملوط البيتن والكحول بدرجة كية كاريقة قيلسية لإزلة مغظم

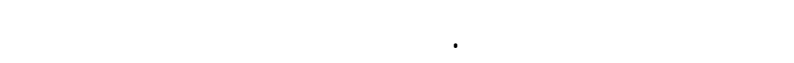

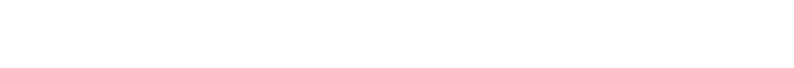

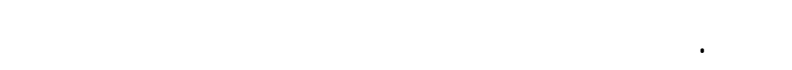

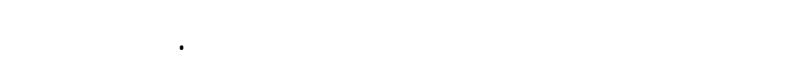

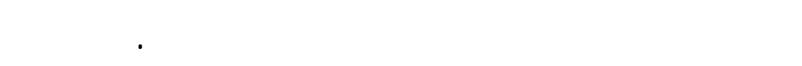

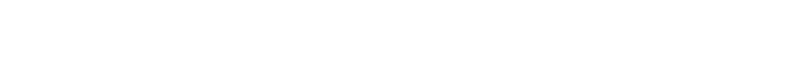

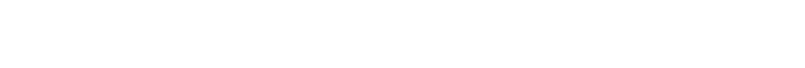

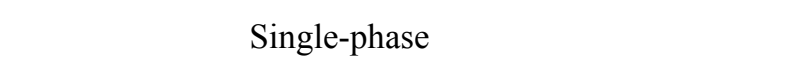

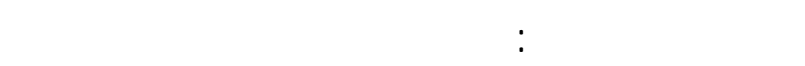

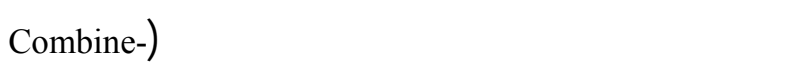
تبهاً للمواصفلت القيلسية الامريكة ASTM (phase

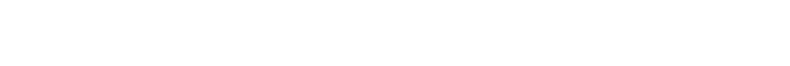

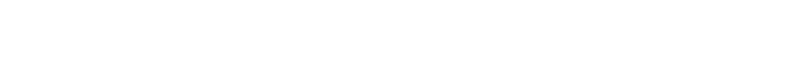

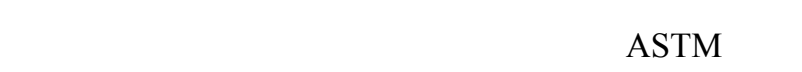
اللبحن (ALT الـ ـ NREL القيلسية للمقارة وذلك بلستخلاص العينت 